\title{
Geoconservation, concept of
}

The exceptional scientific value of certain geodiversity elements justifies the need to implement proper measures in order to assure their conservation. Obviously, not all geodiversity elements should be envisaged for conservation. Most elements have no particular value, and a vast variety of geological resources are exploited everyday to satisfy the needs of modern societies. This means that accurate methods should be used to select exceptional sites that need to be protected and conserved, i.e., geosites. It should be noted that geological heritage (or geoheritage) encompasses in situ occurrences of notable geodiversity elements (minerals, fossils, rocks, soils, and landforms) and ex situ elements usually integrating museum collections. Their management requires different approaches based on different legal settings. While geosites protection is usually assured by nature conservation policies, museum collections fall into the category of cultural assets. The main scope of geoconservation is the conservation of geosites, the basic units of the geological heritage of the Earth, by means of specific inventory, evaluation, conservation, valuing, and monitoring procedures (Henriques et al. 2011). In addition, the management of geological specimens in collections is also considered as geoconservation. Therefore, geoconservation must be regarded a comprehensive strategy fostering the conservation of geological heritage, from identification and assessment to management (Prosser 2013). Initially, the concept of geoconservation was not restricted to the conservation of geoheritage but rather applied to all geodiversity (Sharples 1993, 1995). However, in the recent years, the scope of geoconservation has been narrowed, and it has gained greater specialization. Today, geoconservation is also considered an emergent geoscience discipline (Henriques et al. 2011), like mineralogy, paleontology, or geomorphology. This statement is based on the existence of a growing volume of scientific knowledge on the subject, creation of research schools and teaching, discussion of data and results among experts, and publication of peer-reviewed papers in specialized scientific journals.

Geoconservation is a discipline with five close connections with the society (see i-v below). (i) Concerning scientific practice, two different aspects should be considered. Firstly, selection and assessment of geosites is based on scientific data and procedures. Secondly, conservation of geosites assures the availability of key geodiversity elements, which are essential for advancement of geosciences. (ii) Regarding nature conservation policies, geoheritage corresponds to the abiotic part of natural heritage; alas, current conservation actions still focus on the preservation of biodiversity (Brilha 2002). During its 60 years of activity, the International Union for Conservation of Nature (IUCN) has been promoting biodiversity almost exclusively. Only recently, did the IUCN show some signs of change, by acknowledging the importance of geoheritage in nature conservation. Two IUCN's resolutions stressing the importance of geodiversity in nature and the need to protect geoheritage were approved: the first one in 2008 (Resolution 4.040 - Conservation of geodiversity and geological heritage) and the second in 2012 (Resolution 048 - Valuing and conserving geoheritage within the IUCN Programme 2013-2016). Another link with nature conservation is the necessity to support geoconservation actions by a proper legal framework. (iii) The occurrence of geosites should also be considered by national policies of land-use planning and impact assessment evaluations, as well as by national mineral policies. The need to conserve geosites and the consequent setup of management procedures may imply restrictions in the ordinary use of the territory. For instance, the protection of a geosite may justify changes in initial planning concerning construction of new infrastructures, such as roads, dams, or buildings. During environmental impact assessment, the occurrence of geosites in a certain area should be considered in the final evaluation. (iv) The link between geoconservation and education is twofold: on the one hand, the conservation of geosites with high educative value is a mean to raise awareness on geoconservation, in particular, and on geosciences, in general. A society more and better informed about geology is more willing to accept geoconservation. On the other hand, a society that has some knowledge on the value of geoheritage guarantees a more effective geoconservation. (v) Nowadays, geotourism is considered a niche sector of nature sustainable tourism. Regardless of the different approaches to the geotourism definition, there is no doubt that the existence of geodiversity elements (mainly landforms) as touristic attractions is important to originate economical and social revenues. Geosites with touristic value do not only support economical activities, but they also help visitors to interpret nature and to better understand our planet.

\section{Cross-References}

- Geoconservation Policy

- Geoconservation, History of 
- Geodiversity

- Geosite, Concept of

- Geosites, Management of

- Mining and Geoconservation

\section{References}

- Brilha J (2002) Geoconservation and protected areas. Environ Conserv 29:273-276

- Henriques MH, Pena dos Reis R, Brilha J, Mota TS (2011) Geoconservation as an emerging geoscience. Geoheritage 3:117-128

- Prosser CD (2013) Our rich and varied geoconservation portfolio: the foundation for the future. Proc Geol Assoc 124:568-580

- Sharples C (1993) A methodology for the identification of significant landforms and geological sites for geoconservation purposes. Report to the forestry commission, Tasmania, $p$ 31. Available at http://eprints.utas.edu.au/11747/

- Sharples C (1995) Geoconservation in forest management - principles and procedures. Tasman For 7:37-50

\section{Geoconservation, concept of}

Dr. José Brilha Institute of Earth Sciences, Pole of the University of Minho, Braga, Portugal

DOI: $\quad 10.1007 /$ SpringerReference_385486

URL: $\quad$ http://www.springerreference.com/index/chapterdbid/385486

Part of: $\quad$ Encyclopedia of Mineral and Energy Policy

Editors: $\quad$ Günter Tiess, Tapan Majumder and Peter Cameron

PDF created on: $\quad$ March, 04, 2015 04:10

(C) Springer-Verlag Berlin Heidelberg 2015 